\title{
Analisis Keterampilan Berpikir Kritis Peserta Didik Melalui Model Inkuiri Terbimbing Pada Materi Laju Reaksi
}

\author{
Arviana Ramadhanti, Rudiana Agustini* \\ Program Studi Pendidikan Kimia, FMIPA, Universitas Negeri Surabaya \\ *Corresponding Author. Email: rudianaagustini@yahoo.com
}

\begin{abstract}
This research aimed to analyse students' critical thinking skills on reaction rate material. The learning process was done online using the guided inquiry model. This research applied quantitative descriptive method designed with one group pretest-posttest pattern. Subjects involved in this research was 32 students of class XI MIPA 1 SMA Negeri 1 Taman. Research data was collected from observation and test results through observation sheets of learning model workability and critical thinking question sheets. The data analysis technique used in this research is quantitative analysis with statistical test. The result shows that student's critical thinking skills increased which seen from n-gain score as follows: interpretation indicator as of 0.74 ; inference as of 0.76 ; and explanatory as of 0.86 with high category and analysis indicator as of 0.63 which was middle category. The result of paired sample t-test examination showed the number of sig. (2-tailed) 0.000 that stated whenever found big and significant difference between posttest and pretest scores which indicated the application of guided inquiry model during learning took effect on increasing students' critical thinking skills.
\end{abstract}

\begin{abstract}
Abstrak: Penelitian ini bertujuan untuk menganalisis keterampilan berpikir kritis peserta didik pada materi laju reaksi. Proses pembelajaran dilakukan secara daring menggunakan model inkuiri terbimbing. Penelitian ini menerapkan metode deskriptif kuantitatif yang didesain dengan pola one group pretestposttest. Subyek yang terlibat yakni 32 orang peserta didik kelas XI MIPA 1 SMA Negeri 1 Taman. Data penelitian diambil dari hasil pengamatan dan tes melalui lembar pengamatan keterlaksanaan model pembelajaran dan lembar soal berpikir kritis. Teknik analisis data yang digunakan dalam penelitian ini adalah analisis kuantitatif dengan uji statistik. Hasil penelitian menunjukkan bahwa keterampilan berpikir kritis dari peserta didik meningkat yang dilihat dari rincian n-gain skor berikut: indikator interpretasi senilai 0,74 ; inferensi senilai 0,76; dan eksplanasi senilai 0,86 dengan kategori tinggi serta indikator analisis senilai 0,63 termasuk kategori sedang. Hasil uji paired sample t-test menunjukkan angka sig. (2-tailed) 0,000 yang menyatakan apabila antara nilai posttest dan pretest terdapat perbedaan berarti serta signifikan yang mengindikasikan penerapan model inkuiri terbimbing selama pembelajaran berpengaruh untuk meningkatkan keterampilan berpikir kritis peserta didik.
\end{abstract}

\section{Article History}

Received: 23-01-2021

Revised: 12-04-2021

Accepted: 30-04-2021

Published: 07-06-2021

\section{Key Words:}

Critical Thinking Skill, Guided Inquiry Model, Reaction Rate.

\section{Sejarah Artikel}

Diterima: 23-01-2021

Direvisi: 12-04-2021

Disetujui: 30-04-2021

Diterbitkan: 07-06-2021

\section{Kata Kunci:}

Keterampilan Berpikir

Kritis, Model Inkuiri

Terbimbing, Laju Reaksi.

How to Cite: Ramadhanti, A., \& Agustini, R. (2021). Analisis Keterampilan Berpikir Kritis Peserta Didik Melalui Model Inkuiri Terbimbing Pada Materi Laju Reaksi. Jurnal Kependidikan: Jurnal Hasil Penelitian dan Kajian Kepustakaan di Bidang Pendidikan, Pengajaran dan Pembelajaran, 7(2), 385-394. doi:https://doi.org/10.33394/jk.v7i2.3458

d.

https://doi.org/10.33394/jk.v7i2.3458

This is an open-access article under the CC-BY-SA License.

\section{Pendahuluan}

Kurikulum 2013 mendorong peserta didik menjadi pribadi yang mandiri serta aktif dalam proses pembelajaran. Kurikulum 2013 dikembangkan agar dapat meningkatkan pembelajaran yang berfokus pada aktivitas peserta didik secara berkelompok maupun mandiri, serta penguatan pola pembelajaran kritis. Tujuan kurikulum 2013 bukanlah 
mengalihkan keterampilan dan pengetahuan saja kepada siswa, namun juga berupaya agar kemampuan siswa dalam bepikir tingkat tinggi yang meiputi berpikir kritis, kreatif, analitis, sintesis, dan inovatif dapat terasah melalui pengalaman yang didapat pada saat proses pembelajaran. Keterampilan berpikir kritis harus dimiliki dan dilatihkan pada setiap peserta didik karena di masa yang akan datang keterampilan ini dipandang sebagai suatu permasalahan fundamental dalam kegiatan pembelajaran (Cahyani \& Azizah, 2019).

Pendidikan abad 21 bertujuan untuk mendorong setiap individu agar mampu berpikir secara kritis dalam memilih informasi yang valid dan relevan, mampu berinovasi secara kreatif, mampu bekerja secara mandiri dan kelompok, serta mampu memecahkan masalah kehidupan sehari-hari (Afandi \& Sajidan, 2018). Partnership for 21st Century Skills memuat suatu penjelasan mengenai keterampilan yang wajib terdapat pada setiap individu pada abad 21 yakni keterampilan dalam berpikir kritis yang mampu menuntun siswa untuk dapat bersikap dan berperilaku adaptif guna menyiapkan diri menghadapi tantangan perkembangan zaman (Agustine \& Nawawi, 2020).

Indonesia termasuk dalam peringkat terendah yang menduduki peringkat 62 dari total negara yang berpartisipasi yaitu 70 negara menurut hasil PISA di tahun 2015 di bidang sains (OECD, 2018). Rendahnya peringkat tersebut mengindikasikan kemampuan siswa Indonesia tentang pemahaman konsep sains (IPA) masih rendah. Penyebabnya yaitu kemampuan siswa dalam berpikir kritis belum terlatih selama proses pembelajaran termasuk dalam pembelajaran kimia. Berdasarkan fakta hasil pra penelitian di SMAN 1 Taman Kabupaten Sidoarjo, keterampilan berpikir kritis siswa dinilai masih rendah yang dibuktikan dengan persentase pada indikator interpretasi siswa menjawab benar sebesar $42,5 \%$, inferensi $45 \%$, analisis 37,5\% dan eksplanasi 40\%. Data keterampilan berpikir kritis ini diperoleh dari hasil tes menggunakan instrumen berupa lembar soal keterampilaan berpikir kritis materi laju reaksi. Fakta hasil pra penelitian tersebut membuktikan bahwa tingkat berpikir kritis dalam mengenali masalah yang diberikan belum dikuasai karena ketidakmampuan dalam menginterpretasi, menganalisis, dan menginferensi berbagai informasi yang didapatkan.

Kimia merupakan cabang ilmu IPA yang sebagian besar menjelaskan tentang konsep dan prinsip dari proses terjadinya suau perubahan yang dikenal karena terjadinya suatu reaksi. Terjadinya reaksi kimia dapat mengubah sifat dan struktur suatu senyawa (Effendy, 2017). Bahasan mengenai laju reaksi merupakan bahasan penting yang terdapat dalam pokok materi kimia. Bahasan mengenai laju reaksi dapat menunjang individu untuk berpikir kritis dengan didukung strategi pembelajaran yang tepat. Setiap materi kimia membutuhkan strategi yang berbeda dalam pembelajarannya. Pemberian strategi yang tepat untuk tiap materi pada ilmu kimia adalah salah satu cara agar proses belajar dilaksanakan dengan baik. Hal ini disebabkan tiap-tiap materi memiliki karakteristik yang unik dan berbeda (Hidayatulloh et al., 2020).

Keterampilan berpikir kritis tidak terdapat pada diri manusia sejak lahir, tetapi dapat dilatihkan salah satunya melalui pembelajaran. Keterampilan berpikir kritis adalah keterampilan seseorang untuk berpikir secara rasional dan reflektif. Pemikiran tersebut harus terfokus pada keyakinan dan keputusan yang akan dilakukan. Salah satu ahli yang mengkaji keterampilan berpikir kritis adalah Facione. Terdapat 6 indikator dari keterampilan berpikir kritis menurut Facione yaitu : (1) Menginterpretasi, yaitu keterampilan siswa untuk mengartikan suatu kejadian, data, ataupun sebuah pengalaman; (2) Menganalisis, yaitu keterampilan siswa untuk melakukan penyelidikan mengenai suatu keterkaitan dari sebab akibat dari suatu pernyataan atau peristiwa; (3) Menyimpulkan, yaitu keterampilan siswa membuat kesimpulan berdasarkan data, peristiwa, kejadian dan pernyataan yang relevan dengan bukti dan alasan; (4) Mengevaluasi, yaitu keterampilan siswa untuk menilai suatu 
kebenaran dari informsi yang didapat dengan menggunakan penaaran induktif dan deduktif; (5) Menjelaskan, yaitu keterampilan siswa untuk menjelaskan suatu peristiwa atau fenomena berdasarkan konsep, metode dan pertimbangan yang kuat secara terperinci; (6) Mengatur diri, yaitu keterampilan siswa untuk memastikan bahwa dia telah memahami suatu peristiwa (Facione, 2013).

Pembelajaran menggunakan model inkuiri terbimbing (Guided Inquiry) melibatkan suatu proses inkuiri yang dapat membantu siswa menemukan pengetahuan baru dengan cara melatih siswa untuk meningkatkan kemampuan berpikir kritisnya (Rahmadhani \& Novita, 2018). Model inkuiri juga digunakan untuk membantu siswa memahami berbagai konsep sains dari hasil penyelidikan yang dilakukan sehingga siswa memperoleh suatu pengetahuan baru serta membantu siswa dalam mengembangkan cara berpikir ilmiah karena menempatkan siswa sebagai pebelajar. Model ini mendorong siswa untuk memahami topik-topik secara mendalam dan meningkatkan motivasi belajarnya, sehingga diharapkan tidak hanya dapat meningkatkan pemahaman siswa akan suatu konsep untuk mendapatkan hasil belajar yang baik, namun dapat digunakan untuk meningkatkan keterampilan berpikir kritisnya (Eggen, 2012). Menurut (Matthew \& Igharo, 2018) model inkuiri dengan bimbingan guru adalah suatu model pengajaran yang berperan untuk mengasah keterampilan berpikir peserta didik karena selama prosesnya yang ditekankan adalah kegiatan mencari serta menemukan sehingga lebih melekat.

Berdasarkan uraian di atas, tujuan dalam penelitian ini adalah untuk menganalisis keterampilan berpikir kritis peserta didik pada materi laju reaksi yang dilakukan menggunakan model inkuiri terbimbing, peningkatan keterampilan berpikir kritis siswa pada tiap indikator serta pengaruh model pembelajaran inkuiri terbimbing untuk meningkatkan keterampilan berpikir kritis.

\section{Metode Penelitian}

Penelitian ini menerapkan metode deskriptif kuantitatif yang didesain dengan pola one group pretest-posttest yang mana dilakukan tes awal (pretest) sebelum diterapkan model pembelajaran serta tes akhir (posttest) sesudah pembelajaran memakai model inkuiri terbimbing. Subjek dalam penelitian ini adalah peserta didik SMA Negeri 1 Taman Kabupaten Sidoarjo yang berada pada kelas XI MIPA 1 Tahun Ajaran 2020/2021 dengan jumlah 32 orang. Penelitian ini memperoleh data melalui teknik pengamatan dan tes. Teknik pengamatan digunakan untuk mengamati keterlaksanaan pembelajaran dengan instrumen lembar pengamatan keterlaksanaan pembelajaran dan teknik tes untuk menilai keterampilan berpikir kritis dengan instrumen berupa soal pretest posttest yang berbetuk uraian yang berjumlah 10 butir soal. Instrumen tes yang dipakai pada penelitian ini telah melalui proses validasi oleh dua orang validator dengan kategori sangat layak.

Analisis data statistik disusun dengan bantuan aplikasi SPSS 22.0 untuk menguji hipotesis meliputi uji normalitas serta uji-t (paired samples t-test). Uji normalitas dengan Shapiro-Wilk diaplikasikan dalam rangka mengetahui sebaran data yang nantinya dilakukan pengujian lebih lanjut. Jika hasilnya memperlihatkan nilai Sig. > 0.05 maka dipastikan sebaran data bersifat normal (Sugiyono, 2006). Uji-t berpasangan antara hasil pretest dan posttest dilakukan untuk membandingkan nilai rata-rata siswa dalam berpikir kritis. Keputusan yang diambil dengan melihat hasil uji-t mengikuti pedoman SPSS Indonesia yakni apabila nilai probabilitas atau Sig. (2-tailed) $<0.05$, maka Ha diterima yang berarti bahwa model inkuiri terbimbing yang digunakan selama pembelajaran berpengaruh terhadap keterampilan peserta didik, pada bahasan ini adalah keterampilan berpikir kritisnya dan jika probabilitas atau Sig. (2-tailed) > 0.05, maka Ha ditolak (SPSS Indonesia, 2020). 
Analisis keterlaksanaan pembelajaran dilakukan melalui pengamatan pada proses pembelajaran kemudian memberikan skor berdasarkan kriteria yang dipenuhi guru sesuai dengan rubrik yang tersedia. Selanjutnya keterlaksaan pembelajaran dihitung dalarn persen keterlaksanaan menggunakan rumus sebagai berikut :

$$
\% \text { keterlaksanaan }=\frac{\text { jumlah skor yang diperoleh }}{\text { jumlah skor maksimal }} \times 100 \%
$$

Skor yang didapat selanjutnya dikonversikan sesuai kategori seperti Tabel 1 berikut:

Tabel 1. Pembacaan Skor Berdasarkan Skala Likert

\begin{tabular}{cc}
\hline Persentase & Kategori \\
\hline $0 \%-20 \%$ & Sangat kurang \\
$21 \%-40 \%$ & Kurang \\
$41 \%-60 \%$ & Cukup \\
$61 \%-80 \%$ & baik \\
$81 \%-100 \%$ & Sangat baik \\
\hline
\end{tabular}

Persentase keterlaksanaan model pembelajaran dianggap baik apabila $\geq 61 \%$ (Riduwan, 2011). Analisis keterampilan peserta didik dalam berpikir kritis dintinjau dari perolehan nilai pretest dan posttest yang didapatkan dari pemberian skor pada setiap butir soal sesuai dengan rubik yang tersedia.

$$
\text { Nilai }=\frac{\text { jumlah skor yang diperoleh }}{\text { jumlah skor maksimal }} \times 100
$$

Peningkatan keterampilan berpikir kritis ditentukan dengan menghitung nilai $\langle\mathrm{g}\rangle$ atau n-gain untuk memperoleh gambaran besamya perbedaan antara nilai pretest dan posttest. Perhitungan nilai $\langle\mathrm{g}\rangle$ mengikuti rumus berikut:

$$
\begin{aligned}
& \langle\mathrm{g}\rangle=\frac{\text { nilai posttest-nilai pretest }}{\text { nilai maksimum-nilai pretest }} \\
& \text { (Riduwan, 2011) }
\end{aligned}
$$

Nilai $\langle\mathrm{g}>$ yang diperoleh selanjutnya dikonversikan menurut kategori pada Tabel 2 berikut:

Tabel 2. Kategori Gain Skor

\begin{tabular}{ll}
\hline \multicolumn{1}{c}{ Nilai $\langle$ g $\rangle$} & \multicolumn{1}{c}{ Kategori } \\
\hline$\langle 0,3$ & Rendah \\
$0,7\rangle\langle\mathrm{g}\rangle \geq 0,3$ & Sedang \\
$\langle\mathrm{g}\rangle>0,7$ & Tinggi \\
\hline
\end{tabular}

(Hake, 2002)

Apabila nilai $\langle$ g $>$ adalah $(0,7>\langle\mathrm{g}\rangle \geq 0,3)$ yang termasuk kategori sedang atau nilainya $>0,3$ dengan kategori tinggi maka bisa disimpulkan bahwa terdapat peningkatan keterampilan setelah adanya perlakuan yakni pembelajaran menggunakan model inkuiri terbimbing.

\section{Hasil Penelitian dan Pembahasan}

\section{Keterlaksanaan Model Pembelajaran Inkuiri Terbimbing}

Penelitian ini menggunakan sintaks inkuiri terbimbing menurut (Joyce, et al 2009) yang terdiri dari 5 fase. Keterlaksanaan sintak-sintak model pembelajaran ini diamati oleh 3 orang pengamat menggunakan instrumen lembar pengamatan keterlaksanaan selama 2 pertemuan. Seluruh kegiatan pembelajaran dilakukan secara daring melalui platform googlemeet dengan pokok bahasan faktor-faktor yang berpengaruh terhadap laju suatu reaksi. Persentase keterlaksanaan model pembelajaran selama 2 kali pertemuan disajikan pada Tabel 3 berikut: 
Tabel 3. Persentase Keterlaksanaan Model Pembelajaran Inkuiri Terbimbing

\begin{tabular}{lcc}
\hline \multicolumn{1}{c}{ Sintaks yang dinilai } & \multicolumn{2}{c}{ Keterlaksanaan } \\
\cline { 2 - 3 } & $\begin{array}{c}\text { Pertemuan } \mathbf{1} \\
(\mathbf{\%})\end{array}$ & $\begin{array}{c}\text { Pertemuan 2 } \\
(\mathbf{\%})\end{array}$ \\
\hline Fase 1 : mengenalkan masalah & 93,8 & 97,9 \\
Fase 2 : menghimpun data dan verifikasi & 94,4 & 100 \\
Fase 3 : mengumpulkan data percobaan/eksperimen & 88,9 & 94,4 \\
Fase 4 : mengorganisasikan serta merumuskan penjelasan & 93,3 & 98,3 \\
Fase 5 : mengevaluasi proses penyelidikan & 95,8 & 100 \\
Rata-rata & 93,24 & 98,12 \\
\hline
\end{tabular}

Informasi yang dapat diperoleh dari data pada Tabel 3 di atas adalah persentase keterlaksanaan pembelajaran selama dua pertemuan memakai model inkuiri terbimbing. Pertemuan pertama mendapatkan persentase rata-rata sebesar 93,24\% dan pertemuan kedua $98,12 \%$. Perolehan persentase tersebut menunjukkan bahwa pada pertemuan 1 dan 2 keterlaksanaan model pembelajaran mendapatkan kriteria sangat baik yang dapat mendukung pengembangan keterampilan berpikir yaitu berpikir kritis. Kegiatan peserta didik pada fase 1 berikut dapat menunjang berpikir kritisnya yaitu pada saat merumuskan masalah sesuai dengan fenomena yang disajikan, karena merumuskan masalah tergolong dalam indikator interpretasi. Pada fase 2, peserta didik diminta untuk membuat hipotesis yang merupakan kemampuan menginferensi. Fase 3 dan fase 4 berperan penting untuk menaikkan taraf berpikir kritis yang dimiliki peserta didik, hal ini disebabkan pada fase 3 terdapat kegiatan mengumpulkan data untuk menguji sebuah hipotesis dengan melakukan percobaan secara langsung dan pada fase 4 peserta didik menganalisis serta menyimpulkan hasil percobaan yang dapat mengasah keterampilan berpikir kritisnya. Penelitian lain juga mengungkapkan bahwa fase 4 dalam pembelajaran menggunakan model inkuiri terbimbing termasuk fase yang dominan (Mukmainah \& Bertha, 2020).

\section{Keterampilan Berpikir Kritis}

Penelitian ini membahas tentang empat indikator keterampilan berpikir kritis menurut (Facione, 2013) yaitu indikator interpretasi, inferensi, analisis dan eksplanasi. Instrumen tesnya adalah 10 butir soal uraian yang mencakup empat indikator tersebut. Perhitungan nilai tiap indikator didasarkan atas jawaban peserta didik di settiap butir soal yang diberikan skor sesuai rubrik yang tersedia. Rerata nilai pretest dan posttest keterampilan berpikir kritis peserta didik yang diolah secara matematis dalam bentuk tiap indikator tertera pada Gambar 1 di bawah ini.

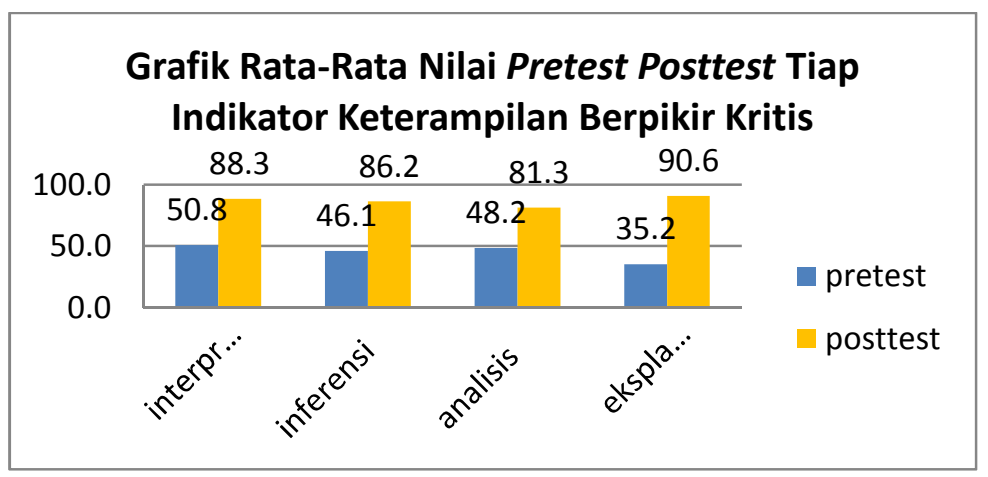

Gambar 1. Rata-rata nilai pretest posttest tiap indikator keterampilan berpikir kritis Grafik di atas menggambarkan bahwasannya secara keseluruhan terdapat peningkatan nilai pada empat indikator keterampilan berpikir kritis. Secara deskriptif rata-rata nilai pretest 
posttest keterampilan berpikir kritis siswa mengalami peningkatan dan jelas terdapat perbedaan, namun secara inferensial nilai tersebut belum tentu memiliki peningkatan yang signifikan. Untuk melihat peningkatan tersebut dilakukan uji t berpasangan (paired sample $t$ test). Hasil rata-rata peningkatan keterampilan berpikir kritis pada tiap indikakor tersebut didukung oleh penelitian (Atik Mukmainah \& Yonatha, 2020) yang menyatakan bahwa ratarata capaian tiap indikator berpikir kritis meningkat setelah diterapkannya model inkuiri terbimbing pada proses pembelajaran. Indikator keterampilan berpikir kritis eksplanasi mengalami peningkatan rata-rata nilai paling tinggi sedangkan indikator analisis mengalami peningkatan terendah. Peningkatan keterampilan berpikir kritis ditentukan melalui perhitungan nilai $\langle\mathrm{g}\rangle$ atau n-gain score yang digunakan untuk membuat acuan seberapa besar perbedaan nilai antara posttest dan pretest. Besarnya peningkatan keterampilan berpikir kritis pada tiap indikator ditunjukkan dari hasil n-gain yang tertera pada Tabel 4 berikut:

\section{Tabel 4. Skor n-gain keterampilan berpikir kritis tiap indikator}

\begin{tabular}{llcccc}
\hline No. & Komponen & \multicolumn{2}{c}{ Nilai rata-rata } & n-gain & Kriteria \\
\cline { 3 - 4 } & KBK & Pretest & Posttest & Score & \\
\hline 1 & Interpretasi & 50,8 & 88,3 & 0,76 & Tinggi \\
2 & Inferensi & 46,1 & 86,2 & 0,74 & Tinggi \\
3 & Analisis & 48,2 & 81,3 & 0,64 & Sedang \\
4 & Eksplanasi & 35,2 & 90,6 & 0,86 & Tinggi \\
\hline
\end{tabular}

Interpretasi yaitu kemampuan membuat rumusan masalah dari suatu permasalahan atau fenomena, yang digunakan untuk memahami serta menjelaskan makna dari permasalahan tersebut (Facione, 2013). Indikator interpretasi pada soal meminta peserta didik merumuskan masalah serta menentukan variabel percobaan. Indikator interpretasi memperoleh n-gain skor sebesar 0,76 yang dikonversikan menjadi kategori tinggi . Perolehan tersebut menunjukkan adanya peningkatan kecakapan peserta didik dalam menginterpretasi yang dilihat dari ratarata nilai pretest sebesar 50,8 ke nilai posttest yakni 88,3 . Peningkatan tersebut disebabkan karena peserta didik telah memperoleh pemahaman konsep yang mendalam dari pengalaman belajar yang didapatkan melalui pembelajaran dengan penemuan yaitu pembelajaran inkuiri dengan bimbingan guru sehingga peserta didik dmampu mengerjakan soal pada indikator interpretasi dengan benar. Selain itu, peserta didik telah memiliki pengalaman dalam menyusun rumusan masalah yang terdiri dari variabel manipulasi dan variabel respon yang saling berhubungan karena telah terbiasa dalam mengidentifikasi variabel percobaan. Penjelasan tersebut didukung oleh pendapat (Indira et al., 2017) yang menganggap peserta didik cukup dengan memberikan penjelasan dan makna dari suatu konsep untuk memahami masalah serta mencermati fenomena yang disajikan di soal kemudian menuliskan suatu rumusan masalahnya dapat menguasai indikator interpretasi.

Inferensi adalah kegiatan mencari dan mengumpulkan unsur-unsur penting yang digunakan dalam menarik suatu kesimpulan atau membuat dugaan sementara (hipotesis) dengan tetap menggunakan informasi yang relevan sebagai suatu acuan (Facione, 2013). Dalam soal pretest dan posttest yang diberikan, indikator inferensi mencakup kemampuan peserta didik membuat hipotesis serta kesimpulan. Indikator inferensi memperoleh skor ngain 0,74 yang dikonversi menjadi kategori tinggi. Nilai pretest peserta didik pada indikator inferensi tergolong rendah yaitu dengan rata-rata sebesar 46,1 karena peserta didik belum mampu menghubungkan variabel respon dengan varibel manipulasi yang diperlukan dalam menarik suatu kesimpulan sehingga jawaban yang dihasilkan tidak sesuai. Selanjutnya, setelah diterapkan pembelajaran dengan model inkuiri terbimbing rata-rata nilai posttest sebesar 86,2 karena peserta didik telah mendapatkan pengalaman belajar untuk membuat 
suatu hipotesis dan kesimpulan sehingga lebih mudah dalam memberikan jawaban yang sesuai. (Fuad \& Zubaidah, 2017) membuktikan bahwa model inkuiri mampu menaikkan keterampilan berpikir kritis pada indikator inferensi karena peserta didik percaya diri dan yakin terhadap kemampuannya dalam membuat suatu kesimpulan.

Analisis merupakan kegiatan mengidentifikasi keterkaitan antara pertanyaan, pernyataan, konsep, deskripsi atau bentuk lainnya (Facione, 2013). Indikator analisis diukur menggunakan soal uraian yang berisi tentang bagaimana percobaan tersebut dapat terjadi. Indikator analisis memperoleh n-gain senilai 0,64 yang merupakan kategori sedang. Indikator analisis adalah indikator dengan capaian peningkatan terendah dengan kategori sedang karena peserta didik tidak menjawab soal secara lengkap sehingga tidak menunjukkan proses analisis yang terjadi. Faktor lain yaitu karena peserta didik kurang teliti dan terlalu singkat dalam memberikan jawaban sehingga jawaban yang dihasilkan tidak maksimal. Penjabaran tersebut juga terdapat pada penelitian (Setianingsih et al., 2019) yang menjelaskan apabila indikator analisis memiliki persentase terendah dan termasuk kedalam kategori cukup artinya sebagian besar siswa masih kurang mampu menganalis pertanyaan dengan baik terhadap suatu masalah. Penelitian lain juga menjelaskan bahwa dalam proses pembelajaran, kegiatan menganalisis data hasil percobaan dengan bimbingan guru dapat membantu peserta didik mendapatkan informasi yang lebih terpercaya untuk menambah dukungan atas penemuan yang dilakukan sehingga dalam hal ini keterampilan analisisnya meningkat yang ditunjukkan dari perolehan nilai posttest dengan rata-rata nilai sebesar 88 (Rahmadhani \& Novita, 2018).

Eksplanasi adalah kemampuan dalam memaparkan hasil penalaran seseorang yang disertai dengan memberikan alasan atas suatu pembenaran dengan bukti yang kuat, berdasar, dan mempertimbangkan sisi konseptual, metodologis dan evidensial (Facione, 2013). Indikator eksplanasi memperoleh n-gain skor sebesar 0,86 dengan kategori tinggi. Indikator ini terdapat dalam 1 butir soal yang membahas mengenai hubungan antara kesimpulan dari hasil percobaan dengan teori yang sebelumnya telah didperoleh yaitu mengenai teori tumbukan. Indikator eksplanasi memperoleh rata-rata nilai pretest terendah karena peserta didik belum bisa menghubungkan kesimpulan yang diperoleh dengan teori yang telah didapat sebelumnya yaitu mengenai teori tumbukan. Hasil penelitian (Febriani \& Ismono, 2020) menunjukkan bahwa indikator eksplanasi dengan skor n-gain senilai 0,76 berada pada kategori tinggi sehingga terbukti bahwa peserta didik telah mampu menjelaskan hubungan kesimpulan yang diambil dengan teori yang telah dipelajari.

Penanaman kebiasaan berpikir kritis memberikan dampak positif bagi siswa. Berpikir kritis mampu mempersiapkan siswa berpikir pada berbagai disiplin ilmu serta dapat digunakan untuk memenuhi kebutuhan intelektual dan pengembangan potensi dirinya (Prihatiningtyas \& Rosmayadi, 2020).

Pengaruh model inkuiri terbimbing terhadap keterampilan berpikir kritis peserta didik dianalisis menggunakan uji hipotesis yakni uji $\mathrm{t}$ (paired sampe t-test). Syarat dari pengujiannya adalah sebaran data harus bersifat normal sehingga digunakan uji normalitas terlebih dahulu agar memperoleh gambaran bahwa data terdistribusi normal atau tidak untuk kemudian dilakukan pengujian lebih lajut. Apabila hasil uji normalitas menunjukkan nilai Sig. > 0.05 dapat diketahui bahwa data tersebut terdistribusi secara normal (Sugiyono, 2006). Berikut ini merupakan hasil uji normalitas Shapiro-Wilk.

Tabel 5. Hasil Uji Normalitas

\begin{tabular}{lccccrcc}
\hline & \multicolumn{3}{c}{ Kolmogorov-Smirnov $^{\text {a }}$} & \multicolumn{4}{c}{ Shapiro-Wilk } \\
\hline & Statistic & df & Sig. & Statistic & df & Sig. \\
\hline Pretest & .165 & 32 & .027 & .942 & 32 & .084
\end{tabular}




\section{\begin{tabular}{lllllll} 
Posttest & .090 & 32 & $.200^{*}$ & .962 & 32 & .306 \\
\hline
\end{tabular}}

Tabel 5 di atas diperoleh dari analisis data menggunakan SPSS 22.0 yang menunjukkan nilai sig. 0,084 pada pretest dan nilai sig. 0,309 pada posttest. Perolehan nilai signifikasi yang lebih besar dari 0,05 tersebut mengindikasikan bahwasannya data yang diuji terdistribusi dengan normal sehingga dapat dilanjutkan ke uji paired sampe t-test. Di bawah ditunjukkan hasil uji paired sample t-test.

Tabel 6. Hasil Uji Paired Sample t-test

\begin{tabular}{cccc}
\hline & $\mathrm{t}$ & $\mathrm{df}$ & Sig. (2-tailed) \\
\hline $\begin{array}{c}\text { Pretest } \\
\text { Posttest }\end{array}$ & $-24,100$ & 31 & 0,000 \\
\hline
\end{tabular}

Dari tabel 6 di atas yang menjadi nilai terpenting yaitu perolehan nilai t dengan angka 24,100 bertanda negatif yang menandakan perolehan nilai pretest lebih rendah dari nilai posttest. Selain itu, nilai sig. (2-tailed) yang menunjukkan angka 0,000 dalam tabel di atas menyatakan apabila antara nilai posttest dan pretest memiliki perbedaan yang berarti dan signifikan. Menurut pedoman SPSS Indonesia nilai Sig. (2-tailed) yang kurang dari 0.05 memberikan kesimpulan bahwa Ha diterima yang menunjukkan bahwa model inkuiri terbimbing memiliki pengaruh positif terhadap peningkatan keterampilan berpikir kritis yang dilatihkan. Hal ini dapat terjadi karena pada fase 3 model inkuiri terbimbing terdapat kegiatan mengumpulkan data untuk menguji sebuah hipotesis dengan melakukan percobaan secara langsung dan pada fase 4 peserta didik menganalisis serta menyimpulkan hasil percobaan yang dapat mengasah keterampilan berpikir kritisnya. Menurut (Husna et al., 2020) dalam penelitiannya, menjelaskan apabila sintak-sintak pada model inkuiri terbimbing terlaksana dengan kategori minimal baik dengan kegiatan pembelajaran antara lain siswa berlatih melakukan penyelidikan dengan membuat pertanyaan, membuat dugaan sementara, mengumpulkan dan menganalisis data hingga menyimpulkan hasil penyelidikan dalam proses pembelajaran maka berpotensi besar dalam memperbaiki kecakapan berpikir kritis. Penelitian lain dari (Febriani \& Ismono, 2020) dan (Setianingsih et al., 2019) juga membuktikan bahwa peserta didik menjadi lebih kritis didukung dengan kenaikan nilai keterampilan berpikir kritisnya setelah dilakukan pembelajaran menggunakan model inkuiri terbimbing yang dibuktikan melalui rata-rata $n$-gain score dalam kategori sedang dan tinggi.

\section{Kesimpulan}

Berdasarkan analisis data dan pembahasan hasil penelitian ini dapat disimpulkan bahwa keterampilan berpikir kritis peserta didik pada materi laju reaksi secara keseluruhan mengalami peningkatan yang dilihat dari n-gain skor pada tiap indikator dengan rincian sebagai berikut: interpretasi sebesar 0,74; inferensi sebesar 0,76; dan eksplanasi sebesar 0,86 yang merupakan kategori tinggi serta indikator analisis sebesar 0,63 termasuk kategori sedang. Hasil uji paired sample t-test menunjukkan angka sig. (2-tailed) 0,000 yang menyatakan apabila antara nilai posttest dan pretest terdapat perbedaan berarti serta signifikan yang mengindikasikan penggunaan model inkuiri terbimbing selama pembelajaran berpengaruh dalam meningkatkan keterampilan berpikir kritis para peserta didik.

\section{Saran}

Saran yang dapat disampaikan berdasarkan hasil penelitian ini adalah; (1) Bagi guru mata pelajaran kimia dapat menjadikan model pembelajaran inkuiri terbimbing sebagai alternatif model pembelajaran untuk meningkatkan keterampilan berpikir kritis siswa khususnya pada materi laju reaksi (2) Bagi peneliti berikutnya yang memiliki keinginan melakukan penelitian 
tentang keterampilan berpikir kritis adalah agar memanfaatkan seluruh indikator keterampilan berpikir kritis Facione yang terdiri dari 6 indikator sehingga diharapkan dapat memberikan informasi lain yang lebih luas tidak hanya berhenti pada empat indikator.

\section{Daftar Pustaka}

Afandi, \& Sajidan. (2018). Stimulasi Keterampilan Berpikir Tingkat Tinggi. UNS Press.

Agustine, J., \& Nawawi, S. (2020). Analisis keterampilan berpikir kritis peserta didik SMA kelas X IPA pada materi virus ( Analysis of science ten grades students' c ritical thinking skills toward virus concepts ). Indonesian Journal of Biology Education, $3(1), 7-11$.

Atik Mukmainah, S., \& Yonatha, B. (2020). Penerapan Model Pembelajaran Inkuiri Terbimbing Untuk Meningkatkan Keterampilan Berpikir Kritis Peserta Didik Pada Materi Laju Reaksi Di Sman 1 Rengel. UNESA Journal of Chemical Education, 9(1), 133-139.

Cahyani, N. I., \& Azizah, U. (2019). Penerapan Model Pembelajaran Inkuiri Terbimbing Untuk Melatihkan Keterampilan Berpikir Kritis Pada Materi Laju Reaksi Kelas XI SMA. UNESA Journal of Chemical Education, 8(3), 320-326.

Eggen, P. D. K. (2012). Strategi dan Model Pembelajaran. PT Indeks.

Facione, P. . (2013). Critical Thinking: what it is and why is counts. measured reasons and the California. Academic Press, Millbrae, CA.

Febriani, D. R., \& Ismono. (2020). Penerapan Model Pembelajaran Inkuiri Terbimbing Untuk Melatihkan Keterampilan Berpikir Kritis Pada Materi Laju Reaksi Kelas XI. UNESA Journal of Chemical Education, 9(2), 187-192.

Fuad, N. M., \& Zubaidah, S. (2017). Improving Junior High Schools' Critical Thinking Skills Based on Test Three Different Models of Learning. Inernational Journal of Instruction, 10(1), 101-110.

Hidayatulloh, R., Suyono, \& Azizah, U. (2020). Analisis Keterampilan Pemecahan Masalah Siswa SMA Pada Topik Laju Reaksi. JPPS (Jurnal Penelitian Pendidikan Sains), 10(01), 1899-1909.

Husna, D., Indriwati, S. E., \& Saptasari, M. (2020). Pengaruh Inkuiri Terbimbing pada Kemampuan Akademik Berbeda terhadap Keterampilan Berpikir Kritis Siswa SMA. Jurnal Pendidikan: Teori, Penelitian, Dan Pengembangan, 2004, 82-87.

Indira, T., Somakim, \& Susanti, E. (2017). Keterampilan berpikir kritis siswa SMP melalui pendekatan pendidikan matematika realistik. Jurnal Pendidikan Matematika, 1(2), $61-75$.

Matthew, B. M., \& Igharo, O. K. (2018). a study on the effects of guided inquiry teaching method on students achievement. Journal of International Researcher in Nigeria, 2(1), 134-140.

Prihatiningtyas, N., \& Rosmaiyadi, R. (2020). Kemampuan Berpikir Kritis Matematis Siswa Dalam Model Pembelajaran Jucama pada Materi Trigonometri. Jurnal Kependidikan: Jurnal Hasil Penelitian dan Kajian Kepustakaan di Bidang Pendidikan, Pengajaran dan Pembelajaran, 6(1), 27-37. doi:https://doi.org/10.33394/jk.v6i1.2301 
Rahmadhani, P., \& Novita, D. (2018). Keterampilan Berpikir Kritis Siswa Pada Materi Laju Reaksi di Kelas XI MIA SMA Negeri 1 Manyar. Jurnal Pembelajaran Kimia Universitas Negeri Malang, 3(2), 19-30.

Setianingsih, R., Sumarni, W., \& Mahatmanti, F. W. (2019). Analisis Kemampuan Berpikir Kritis Siswa Melalui Penerapan Model Pembelajaran Inkuiri Terbimbing. Chemistry in Education Journal, 1(2), 188-202.

SPSS Indonesia. (2020). Cara Melakukan Uji Normalitas Kolmogorov-Smirnov dengan SPSS. http://www.spssindonesia.com/2020/01/uji-normalitas-kolmogorov-smirn ovspss.html

Sugiyono. (2006). Statistika untuk Penelitian. Alfabeta. 